\title{
A világtörténelem legnagyobb nemzetközi közlekedésfejlesztési projektje
}

\begin{abstract}
A szerző gondosan válogatott angol és német szakirodalmi háttéranyagra támaszkodva ismerteti a - közismert angol nevén Belt and Road - közlekedési gigaprojekt megszületésének történelmi elözményeit, majd részletekbe menően elemzi az európai gazdasági szakértők szerint elsősorban Kína gazdasági expanzióját szolgáló "Új Selyemút" megvalósításának tengeri és vasúti közlekedési alternatíváit és eszközrendszerét.
\end{abstract}

DOI 10.24228/KTSZ.2020.5.1

\section{Erdősi Ferenc DSc}

\author{
professor emeritus \\ e-mail: erdosi@rkk.hu
}

\section{BEVEZETÉS}

Korábban a legrangosabb infrastruktúrahálózat fejlesztések létesítményei (az északamerikai óceánok közötti pacific vasutak, az oroszországi Transzszibériai Vasút, a német autópálya-hálózat, a Kieli-csatorna stb.) az adott ország területén épültek és döntően a belföldi közlekedést, a tartományok közötti közlekedési kapcsolatokat szolgálták. Funkcionális szempontból kivételt képezett a világrészek közötti tengerhajózás és kereskedelem érdekében megépített Szuezi- és Panama-csatorna, azonban ezek is csupán egyetlen ország (Egyiptom, illetve Panama) területén allokálódtak. A 20. sz. elején az Oszmán Birodalom német segítséggel ugyan formálisan létrehozta a (Berlin)-Isztambul-Bagdad vasúti összeköttetést, de teljes hosszban nem közlekedtek rajta vonatok, a világháború után pedig az új államhatárok felszabdalták [1].

A lényegében kontinens nagyságú Kinai Népköztársaság, miközben a saját területét gazda- gította a világ leghosszabb nagysebességű vasút és gyorsforgalmi úthálózatával, 2013-ban meghirdette a több kontinensre kiterjedő „Egy út, egy övezet" (One Road, One Belt) közlekedési infrastruktúra programját, amelynek elnevezése közben egyszerüsítve B\&R-re (Belt and Road) módosult. Ezen belül az Új Tengeri Selyemútra vonatkozó rész az MSR rövidítés megnevezést vette fel. Médiumokban gyakran csupán „Új Selyemút” elnevezéssel illetik a tengerekre és szárazföldekre egyaránt kiterjedő teljes projektet [2].

\section{A B\&R ELÖZMÉNYEI}

A középkori Selyemútnak nagy jelentőséget tulajdonítottak a 19/20. századi európai földrajztudósok is, többek között Ferdinand von Richthofen, aki 1877-től többször bejárta a belső- és közép-ázsiai selyemutat. Ma is többen visszautalnak a történelmi (valóságra) gyökerekre. Kínában és újabban Európában is sokszor emlékeztetnek a szerzők arra, hogy a 15. sz.-ban a Ming-dinasztia idején 
Cseng (Zheng) tengernagy az európaiaknál nagyobb hajóival eljutott Kelet-Afrikába és kolóniákat is létesített. Gyakoriak az olyan vélemények, hogy Kína ma nem tesz mást, mint csupán visszaállítja egykori, az országhatárain túlra terjeszkedő hatalmát. A valóságban azonban a középkorihoz képest összehasonlíthatatlanul nagyobb területre kiterjedő, tartós és határidőhöz (2049-hez, a Kínai Népköztársaság kikiáltásának centenáriumához) kötött tervszerü expanzióról van szó.

A nosztalgikus „Új Selyemút” erős utalás és egyben romantikus reminiszcencia a régmúlt értékeire, elmélyítve az irántuk érzett tiszteletet, miközben az utódja (többféle funkcióval felruházva) egy újfajta célrendszerben elhelyezkedve a mai Kína számára már mást jelent (még a jelentőségében is). Ezért csak bizonyos vonatkozásban és értelemben beszélhetünk a Selyemút reneszánszáról. Nobis [3] szerint ma is erős a historizáló politika által sugallt kölcsönkapcsolat hangsúlyozása az egykori és mai kreáció között, ezért nincs értelme firtatni, hogy „...az „Új Selyemút” lett-e tradicionálisabb, vagy az egykori Selyemút lett modernebb a mai nézetrendszerünkben” (p. 209).

A B\&R legújabb kori előzményének tekinthető az ENSZ által már az 1960-as években kezdeményezett (Szingapúr-Isztambul viszonylatú) „Trans-Asian Railway (TAR)”, majd a Hillary Clinton-féle „Új Selyemút” [4].

$\mathrm{Az}$ amerikai álmokkal szemben (amelyekből nem sok minden valósult meg) Fardella [5] úgy látta, hogy a B\&R maradt az egyetlen létező és müködőképes, széles horizontú, nemzetközi kezdeményezés. Kína elöször szükebb körü regionális fejlesztési projektekkel indította el 2000-ben nyugati irányban a gazdasági expanzióját. A „Western Development Strategy” célja az ország elmaradottabb nyugati tartományainak fejlesztése volt a közép-ázsiai országokkal való együttműködéssel. A vasúthálózatok összekötése, közös fejlesztése képezte a stratégia legfőbb eszközét [6].

\section{A B\&R CÉLRENDSZERE, ESZKÖZEI ÉS A KÍNA ÁLTAL VÁRT EREDMÉNYEI}

Kína új kormányzata a születőben levő gazdasági/politikai szuperhatalom léptékeivel arányos mértékben újfajta globalizáció és világkormányzás megvalósítására törekszik [6]. Ebben megfelelő részvételt kell, hogy kapjanak az általa patronált elmaradott és feltörekvő országok [7]. Ugyan Kína generális céljának ilyenfajta megközelítésű interpretációját Noesselt [8] inkább csak intuitív terméknek véli, de ennek ellenére szerintünk az igazságtartalma jóval nagyobb a puszta spekulációnál.

Kina globális ambícióját érthetővé teszi a világról alkotott „sinocentrikus” szemléletmódja, ami nem valamiféle túlhaladott történelmi örökség, hanem ma is érvényes, amikor a világ vezető hatalmának elnyerésére jó esélye van [9].

A B\&R külső indítéka, hogy egyfajta alternatív módot érvényesitsen (a maga által kreált szabályrendszer alapján) a nemzetközi gazdasági/ kereskedelmi kapcsolatrendszerben a "nyugati” országokkal (az Egyesült Államokkal, Európával, sőt Oroszországgal) szemben az elsösorban Dél- és Közép-Ázsiában müködtetett üzleti tevékenységében. Kínai hivatalos dokumentumok a szerteágazó célrendszert (és a különböző elemeit) természetszerűen diplomatikus narratívával adják elő. A legáltalánosabb megfogalmazásban a $\mathrm{B} \& \mathrm{R}$ célja a regionális és globális integráció elősegítése, magasabb szintre emelése, és ezzel Kínában és a vele kapcsolatban levő országokban a makrogazdasági növekedés, illetve a jólét elősegítése [10]. Ezért a B\&R koncepciója pluralista - mivel célja a multipoláris világrend - és egyben nyitott minden ország csatlakozására.

Kína hangsúlyozza, hogy a kezdeményezésnek nincsenek politikai vagy katonai céljai, hanem a békés gazdaságfejlesztés a cél a kölcsönös tisztelet, a be nem avatkozás, az egyenlöség és a kölcsönös haszon (a win-win elv betartása) alapján [11]. 
Kína ugyan valóban ügyel arra, hogy a B\&R kezdeményezés ne utaljon valamiféle katonai terjeszkedési törekvésre, azonban nyilvánvaló, hogy az interkontinentális gazdasági kapcsolati háló biztonságának megőrzése nem mindig sikerülhet bizonyos szintű katonai jelenlét nélkül.

Steck [12] úgy látta, hogy a B\&R nem stratégia, de még csak vízió sem (pedig némelykor ilyen müfajnak nevezik a hivatalos kínai dokumentumok is), hanem folyamat. A célok megvalósításának fó eszköze a nemzetközi infrastruktúrákból és a velük kapcsolatos egyéb (társadalmi, gazdasági) komponensekből álló komplex fejlesztőrendszer létrehozása nagyszabású beruházásokkal, tudományos és kulturális együttmüködéssel.

A B\&R projekt természetesen nem választható el Kína erőteljes gazdasági szerkezetváltozásával és szociális problémáival kapcsolatos kényszerhelyzetektől sem. A hazai távolsági közlekedési infrastruktúra-hálózat és lakásépítési program befejeződésével kialakult építési/jármügyártási kapacitásfelesleg lekötéséhez piacokat kellett találni külföldön [13].

A kezdeményezés eredményes megvalósítása Pekinget a globális nemzetközi rendszer középpontjává teheti, mert a kínai gazdasági és politikai modell az elmaradott országokban a szegénység enyhítésében, gazdasági támogatásukban jóval rugalmasabb és életképesebb, mint az eddigi nyugati rendszerek. A kínai modell érvényesülése egy olyan új paradigma megvalósulásához vezethet, amely esélyt ad a globalizációs folyamattal járó anomáliák mérséklésére, kiegyensúlyozására [14].

A világ első kereskedő nemzete és második legnagyobb gazdasági hatalma „sarkára állt” az (egyelőre) szuperhatalom Egyesült Államokkal folytatott gazdasági, technológiai és a politikai befolyásolásra is kiterjedő versenyben [15].

\section{SZEMIGLOBÁLIS KITERJEDÉS - TRILLIÓ DOLLÁROS FINANSZÍ- ROZÁS}

A B\&R gigaprojekthez csatlakozó országok körének alakulásában a távolságnak (így a szom- szédságnak) csupán másodlagos szerepe volt. A hosszú közös határ ellenére nem terjedt ki a dél-kínai tengeri szigetek hovatartozásával kapcsolatos nézeteltérések miatt Kínával szemben „elhidegült” és ráadásul Délkelet-Ázsiában középhatalmi vezető szerepre törekvő, szuverenitására nagy hangsúlyt fektető Vietnámra, sem a nagyhatalmi ambícióit nem is tagadó Indiára. A B\&R kiterjedésének időbeni folyamatában viszont megállapítható bizonyos fokú összefüggés a glóbuszon való elhelyezkedéssel. (Legkésőbb a távoli térségek váltak részeseivé.)

2017-ben a 68 csatlakozott ország a világ népességének 65\%-át, de GDP-jének csak a 40\%át képviselte. Tehát túlnyomóan a világátlagnál alacsonyabb jövedelmű országokat kooptált a kezdeményezés. 2019. áprilisig Kína 126 országgal és 29 nemzetközi szervezettel írt alá együttműködési dokumentumot [16]. Akkorra már Ázsián kívül Észak- és Nyugat-Afrika, a Karib-térség és Dél-Amerika több országa is a kezdeményezés részévé vált. Európában Görögország (2018. augusztus) és Olaszország (mint az első G7 tag) csatlakozása (2019. március) keltette a legnagyobb visszhangot, de még kevesebb megértés fogadta Svájc és Luxemburg szerződését [17].

A B\&R (az elődeivel ellentétben) erős finanszírozási háttérre számíthat. A fél világra kiterjedő, rendkívül szerteágazó beruházási/fejlesztési tevékenységek teljes költségét az OECD csupán a 2017-2027. évi időszakra 1-3 trillió USD-re becsülte.

A külföldi beruházások a (többségükben) kínai állami pénzintézetek/alapok által nyújtott hosszú lejáratú kölcsönökből létesülnek, ezért kisebb a kockázatérzékenységük mint a magántőke-befektetőknek.

A 2015-ben 100 milliárd USD tőkével alapított Ázsiai Infrastrukturális Fejlesztési Bank (AIIB) elsődleges rendeltetése az Ázsiában indokolt infrastruktúra-fejlesztési igények felmérése, a regionális integráció és a gazdasági fejlődés elösegítése, a társadalmi szolgáltatások elérhetöségének javítása és ezekhez a megfelelő hitelek biztosítása. Kína részesedése a részvényekből 26,63\%. E bank 2016. januártól működik [18]. 
A Selyemút Alap (Silk Road Fund - SRF) bankoktól és az OPEC keretében folyó beruházásoktól független, kifejezetten a B\&R-t szolgáló állami szerv, amelyet 2014. novemberben meglehetősen szerény (40 milliárd USD) tőkével alapítottak Pekingben.

\section{Az Új Fejlesztési Bankot (New Development} Bank - NDB) a BRIC-országok alapították 2014-ben 100 milliárd USD tőkével. Kína a többségi (41\%-os) részvénypakettel és a bank központjának Sanghajba allokálásával vezető szerepet tölt be a nemzetközi pénzintézetben [19]. Egyes esetekben a beruházások hitelezői között olyan rangos nemzetközi pénzintézetek is megjelennek mint az European Bank for Reconstruction and Development (EBRD) és a sanghaji Cooperation Organization Bank [20].

Miután nem csupán fejletlen (sőt kifejezetten szegény) és ráadásul politikailag bizonytalan országokban történik a közlekedési, energetikai és szociális infrastruktúra-beruházások többsége (ahol gyakran váltják egymást a Kínához való viszony tekintetében is különböző rezsimek), a befektetett tőke visszafizetésének (és még inkább nyereség elkönyvelésének) erős a kockázata. Nem csupán a fegyveres konfliktusok, hanem az egy pillérre (pl. olajkitermelésre és -iparra) épült nemzetgazdaságok körében is aggasztó helyzetek alakultak ki a 2010-es években a kínai beruházások számára (Szíria, Irán, Irak, Pakisztán, egyes kelet-közép-európai országok stb.). Az OECD számításai szerint 2017-ben 100 milliárd USD-nél nagyobb volt a kínai beruházókkal szembeni adósság összege, amelynek visszafizetése bizonytalanná vált.

Kína nagyszabású tengeri útvonal fejlesztési projektjének megértéséhez ismerni kell tengerhajózási szektorának teljesítőképességét.

\section{KÍNA TENGERI SZÁLLÍTÁSI NAGYHATALOM}

Felmerülhet a kérdés, hogy az MSR gigaterv megvalósításához a köztudatban szárazföldi birodalom a tengeri szállításhoz elegendő képességekkel rendelkezik-e?

A „világ ipari mühelyének” sajátossága, hogy (a szén kivételével) fosszilis energiahordozó és ipari nyersanyag szükségletének többségét tengerentúlról (Perzsa-öböl térségéből, Ausztráliából, Brazíliából, Afrikából stb.) kénytelen fedezni.

Kina igyekszik magát függetleníteni a külföldi szállitótársaságoktól, ezért a hajógyártásban az élbolyba küzdötte fel magát. (Kiváltképpen a 20 ezer TEU-nál nagyobb konténerhajók vízre

1. táblázat: A világ első tíz konténerkikötője sorrendjének alakulása, 1975-2017, millió TEU

\begin{tabular}{|c|c|c|c|c|c|c|c|}
\hline \multicolumn{2}{|c|}{ 1975-ben } & \multicolumn{2}{|c|}{ 1995-ben } & \multicolumn{2}{|c|}{ 2008-ban } & \multicolumn{2}{|c|}{ 2019-ben } \\
\hline New York & 1,73 & Hongkong* & 12,6 & Szingapúr & 29,9 & Sanghaj & 43,3 \\
\hline Rotterdam & 1,08 & Szingapúr & 10,8 & Sanghaj & 28,0 & Szingapúr & 37,2 \\
\hline Kobe & 0,90 & Kaohsiung & 5,2 & Hongkong & 24,5 & Ningbo & 27,5 \\
\hline San Juan & 0,88 & Rotterdam & 4,8 & Shenzhen & 21,4 & Shenzhen & 25,8 \\
\hline Hongkong* & 0,80 & Puszan & 4,5 & Puszan & 13,4 & Guangzhou & 23,2 \\
\hline Oakland & 0,52 & Hamburg & 2,9 & Dubai & 11,8 & Puszan & 22,0 \\
\hline Seattle & 0,48 & Long Beach & 2,8 & Ningbo & 11,2 & Qingdao & 21,0 \\
\hline Baltimore & 0,42 & Jokohama & 2,8 & Rotterdam & 10,8 & Hongkong* & 18,3 \\
\hline Bréma & 0,41 & Los Angeles & 2,6 & Qingdao & 10,0 & Tiencsin & 17,3 \\
\hline Long Beach & 0,39 & Antwerpen & 2,3 & Hamburg & 9,7 & Dubai & 14,8 \\
\hline
\end{tabular}

*Hongkong igazgatásilag a Kínai Népköztársaság része, kikötője főként Kína külkereskedelmét szolgálja.Forrás: [21] 
bocsátásával.) Tulajdon tekintetében (dwt-ben számolva) Kína kereskedelmi flottáját csupán Görögország és Japán előzi meg. A világ tíz legforgalmasabb tengeri konténerszállító vonala közül hat Kínából indul.

Az ország tengeri külkereskedelmi forgalma a kikötőiben összegződik. Az 1. táblázat adatai jól érzékeltetik Kína gazdaságának egyedülállóan gyors és óriási méreteket produkáló fejlődését. Ma a világ tíz legnagyobb konténerkikötőjéből hét kínai. (A hasonló népességszámú India kikötői közül egy sem szerepel a világ harminc forgalmasabb konténerkikötője között.)

\section{AZ ÚJ TENGERI SELYEMÚT (MSR)}

A szárazföldi birodalom szerepre korlátozottan Kína jelenléte az óceánokon az 1980/90-es évekig szerény volt. Ma viszont Kína számára a B\&R kezdeményezésen belül a tengeren elérhető (a szárazföldi sokszorosát kitevő számú) nemzetgazdaságokkal létesithető kapcsolatoknak azért van különleges jelentösége, mivel külkereskedelmének több mint $90 \%$-át a tengerhajózás bonyolítja le.

Az M\&R két alapvető politikai/gazdasági célja: - olyan politika folytatása, amely biztosítja a partnerországokkal való biztonságos kereskedelmi kapcsolat fenntartását a legkülönbözőbb tengeri útvonalakon, beleértve a természetes szorosokat és a nagy hajózási csatornákat;

- továbbá, hogy a tengeri útvonalak mentén a lehető legtöbb kikötőben szerezzenek kínai hajózási társaságok üzemeltetési koncessziót, ezzel megkönnyítve a piacok elérését [22].

E két cél ugyan formálisan különböző, azonban időnként a megvalósításukkor geopolitikai gyakorlatként kapcsolódnak össze. Az MSR a világkereskedelem térbeli átrendezödését gyorsitja azzal, hogy a tengeri forgalom súlypontja az Egyesült Államok által ellenörzött Csendes-és Atlanti-óceánról lassan áttolódik a Kina által egyre jobban befolyásolt Indiai-óceánra, illetve a három kontinenst (Ázsiát, Afrikát és Európát) összefüző közlekedési útvonalakra (1. ábra) [23].
Kína számára valamennyi interkontinentális hajózási útvonal közül az Ázsiát délről megkerülő és Európába vezető vált kiemelkedő fontosságúvá. E foútvonalon azonban több (geostratégiai szempontból érzékeny) szűkület (természetes tengerszoros, csatorna) mintegy "fojtópontként” időnként kritikus helyzetet teremt a tengerhajózás számára.

\subsection{Az útvonal kritikus szakaszai, „fojtó- pontjai”}

Az Európával összekötő útvonal része a Szuezi-csatorna békeidőbeli használatának csupán a hajók mérete szab határt. A történelmi tapasztalatok arra intik Kínát, hogy diplomáciai eszközökkel és a csatorna közelében logisztikai központok, ipari üzemek épitésével jó viszonyt ápoljon Egyiptommal.

A Vörös-tenger déli bejárata, a Báb el-Mandebszoros térségét mindaddig komolyan veszélyeztették a szomáliai kalózok, ameddig nem jelentek meg néhány ország hadihajói. Legsikeresebbnek a kínai kontingens bizonyult [24].

Még érzékenyebb pont Kína számára a Hormuzi-szoros, amelyen keresztül áramlik a Kína által importált olaj $80 \%$-a [25].

A tágabb értelemben vett Indiai-óceán ellenörzésére ugyan nem meglepő módon a nagyhatalommá avanzsáló India tart igényt, ám a messze legnagyobb erőkkel az utóbbi időkig az U. S. Navy van jelen támaszpontjaival (Diego Garcia-val a központjában) [26].

A globális tengerhajózás fővonalain lévő "fojtópontok" közül a Szingapúr és Indonézia közötti Malaka-szoros a teljes áruszállítás volumenét tekintve is a legforgalmasabb, ráadásul a Panama-csatornát tizenkilencszer, a szuezit négyszer múlja felül az olajszállításban [27]. Ezért forgalmi jelentősége és egyben használatának kockázata különlegesen nagy: a 21. századi Új Tengeri Selyemút megvalósíthatósága a tét.

Ugyan Kína a Pakisztánból és Mianmarból belső tartományai felé indított folyosókkal némileg képes csökkenteni a Malaka-szorosan 


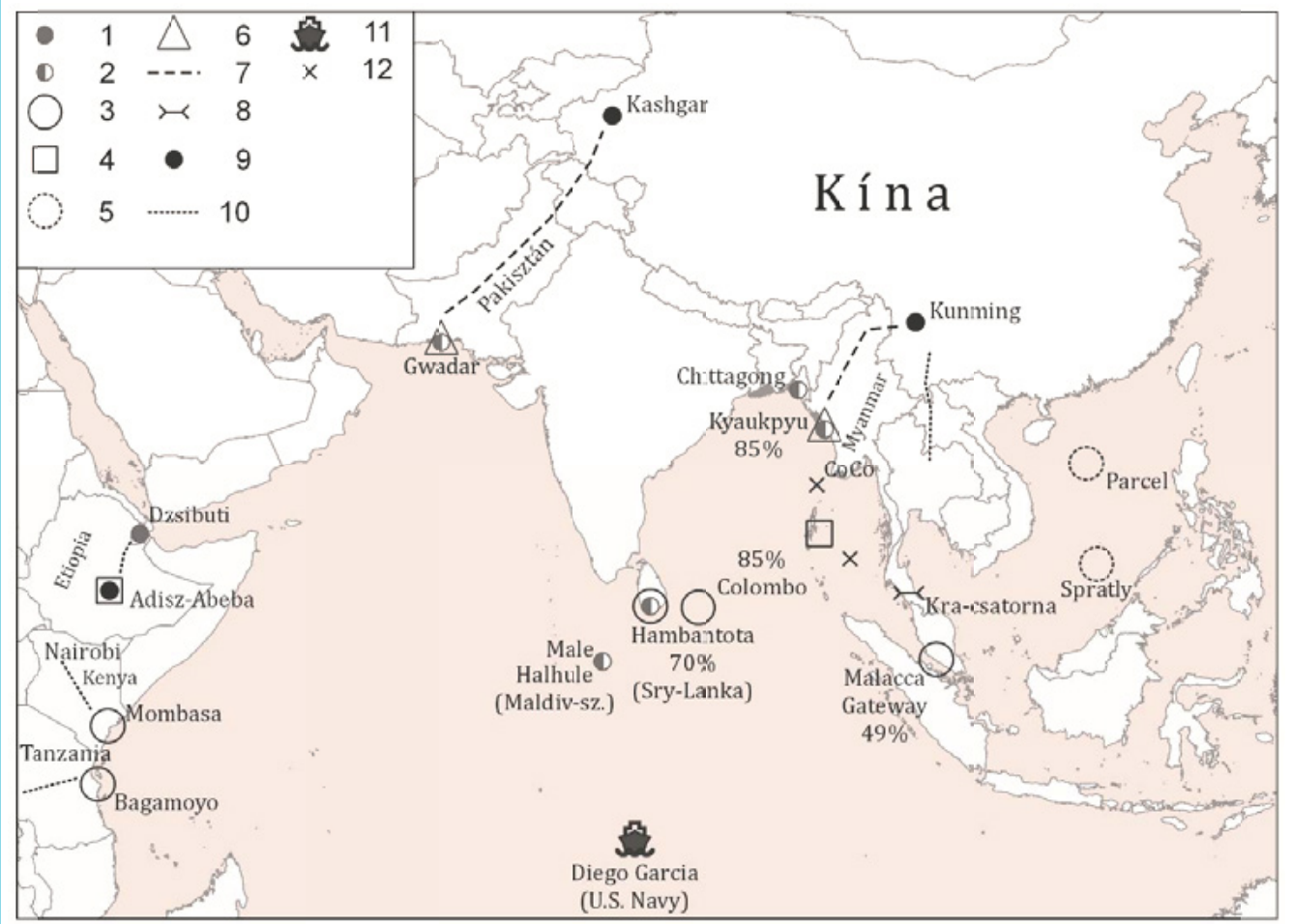

Jelmagyarázat: 1 - Legális hadikikötő; 2 - Kínai hadihajókat időnként kiszolgáló kikötők; 3 - Kínai többségi tulajdon, százalékarány; 4 - Kínai manőverekhez igénybe vehető sziget; 5 - Kína és Vietnám által vitatott hovatartozású szigetcsoportok; 6 - Kínába vezető korridor kikötője; 7 - Szárazföldi korridor (szénhidrogén-vezeték, autóút, tervezett vasút); 8 - Tervezett hajózócsatorna; 9 - Korridorvégpont kínai városok; 10 - Új, működő (Kína által épített) vasút; 11 - USA haditámaszpont; 12 - India haditengerészeti támaszpontjai szigeteken.

Forrás: több tanulmány adataiból szerkesztette a szerző.

áthaladó forgalmát, de radikális megoldást csak a Maláj-félsziget átvágásával létrehozott Kra-csatorna hozhatna.

Azonban a megtakaritható úthossz jelentéktelensége miatt békeidőben a Távol-Kelet által generált forgalomnak csupán kis része venné igénybe a legnagyobb hajók áthaladását is lehető tevő mesterséges vízi utat [28]. Mindezek figyelembevételével a hangzatos és sokféle (politikai, tengerészeti) narratívában fellelhető Malaka-dilemma tárgyilagosan megitélve tulajdonképpen nem létezik. (A Szunda- és Lomboki-szoros átmeneti alternatíva lehet.)

Nem lehet megkerülni azt a kérdést, hogy Kina számára hogyan alakul az általa nagymérték- ben elönyben részesített tengeri útvonal jelentösége. Válaszként a helyzet alakulását befolyásoló néhány tényező már felsorakoztatható. Ezek

- Kína gazdaságszerkezetének és exportkontingensének alakulása következtében a jóval kisebb anyagigényü termékek exportja csökkentheti az interkontinentális szállítás iránti igényt;

- A belső fogyasztás növekedése az export mérsékléséhez, de ugyanakkor nagyobb tömegű élelmiszer- és használaticikk-importhoz vezet immár Afrikából és Amerikából, míg Latin-Amerika a trópusi cikkek behozatalában a mainál rangosabb pozíciót foglalhat el;

- A transzeurázsiai („Új Selyemút”) szárazföldi pályák kapacitásának változása érde- 


\begin{tabular}{|c|c|c|c|}
\hline Kikötő (ország) & A bérleti idő hossza & $\begin{array}{l}\text { Az érdekeltség } \\
\text { részaránya }\end{array}$ & Megjegyzés \\
\hline Colombo (Srí Lanka) & 35 & 85 & \\
\hline Hambantota (Srí Lanka) & 99 & 70 & $\begin{array}{l}\text { tömeges helyi tiltakozás, konfliktus a la- } \\
\text { kosság és a kormány között, pedig az ipari } \\
\text { zóna munkahelyeket teremt }\end{array}$ \\
\hline Gwadar (Pakisztán) & 40 & 85 & \\
\hline Kvaukpu (Mianmar) & 50 & 70 & \\
\hline Malacca Gateway (Malajzia) & 99 & 49 & \\
\hline Kuantan (Malajzia) & 60 & $\cdot$ & \\
\hline Dzsibuti/Obock (Dzsibuti & 10 & - & $\begin{array}{l}\text { haditengerészeti támaszpont a Báb el- } \\
\text { Mandeb-szoros bejárata előtti Âdeni- } \\
\text { öbölben }\end{array}$ \\
\hline Muara (Brunei) & 60 & - & \\
\hline Feydhoo Finolhu (Maldív-szigetek) & 50 & . & \\
\hline
\end{tabular}

Forrás: [21]

mileg nem befolyásolja az Indiai-óceánon átvezető déli tengeri útvonal jelentőségét. (A tengeri útvonalon esetleg bekövetkezö krízis viszont komoly kihívást jelentene a szárazföldi útvonalak teljesítőképessége számára.);

- A jeges-tengeri északi hajóúton a 2020-as évek elején annyi áru mozog Ázsia és Európa között mint a transzázsiai vasutakon. Mindamellett az Arktisz-forgalomnak még sokáig csak gyenge elszívó hatása lehet az indiai-óceánira [28].

\subsection{Az MSR kikötőállományának rendelte- tése}

Az angol világbirodalom a legértékesebb koronagyarmata, India, valamint a kiemelkedő stratégiai/kereskedelmi emporiumai (Szingapúr, Hongkong) eléréséhez vezető tengeri útvonal mellett Gibraltártól kezdve Máltán, Port Szaídon és Ádenen keresztül nem csupán hajóellátási, hanem haditengerészeti/ katonai támaszpontokat is berendezett. Kina most nem tesz mást, mint keleti irányból nyugat felé haladva alakítja ki a (különböző mértékben és módon birtokolt) kikötői láncot, amelynek segítségével hatékonyabbá és megbízhatóbbá teheti a mögöttes területek- kel való kereskedelmét, vagy hozhat létre árugyüjtő/elosztó csomópontokat, forgalmi „fordítókorongokat”.

Az MSR meghirdetése óta 2018 végéig eltelt idöszakban kínai vállalatok már harminc ország ötven kikötőjében végeztek jelentősebb beruházásokat és vettek részt valamilyen szinten az üzemeltetésükben [29]. A Sárga-tenger partjától Nyugat-Európáig tartó 13-14 ezer km hosszú tengeri út melletti kikötőláncon belül a hangsúlyt a kínai politika a Vörös-tenger déli bejáratáig terjedö szakaszon mindössze 8-10 kulcsfontosságú kikötőre helyezte, amelyekben magas arányú részesedés birtokában üzemeltetőként hosszú időre berendezkedett. A Kína által birtokolt (gateway és hub funkciójú) kereskedelmi kikötők általában alkalmasak az időnként megjelenő hadihajók kiszolgálására is.

A tengeri útvonal és kereskedelem védelmére (kalózoktól is) a dzsibutibeli Obock hadikikötő és részlegesen a pakisztáni Gwadar rendezkedett be (1. ábra és 2 . táblázat).

A kikötőüzemeltetési jogok megszerzésére irányuló kínai expanzió nagy hulláma a 20152017-es években söpört végig Ázsiában, KeletAfrikában és Európában. 


\begin{tabular}{l} 
3. táblázat: Kínai cégek részaránya, európai kikötók iizemeltetöi társaságainak \\
részvénytökéjéböl \\
\multicolumn{1}{|c|}{ Ország }
\end{tabular}

Forrás: [33]

Erre különösen ott volt lehetőség, ahol a kikötő gazdaságilag ellehetetlenedett (nem utolsósorban a teljes müszaki elavultsága, erös forgalomcsökkenése miatt) és a tulajdonos állam nem volt képes a szükséges ráfordítások biztosítására. Ezért a kínai állami cégek az általuk nyújtott hitelből bővítették, korszerüsítették a kikötőket. Gyakran azonban elmaradt a kölcsön visszafizetése, és így a kikötőüzemeltető társaság a részvényeinek nagy részét kénytelen volt a kínai cégnek átadni [31].

Nyugati elemzők a legtöbb esetben „adósságcsapdáról" beszélnek. Ahol nem kerülhetett sor a beruházott tőke visszafizetésére, ott valóban csak ez lehetett a kompenzáció módja. Más kikötőkben pedig a kínai cégek „bevásárolták magukat" a kikötőbe, azaz részvények vételével váltak birtokossá.

E folyamat, Kína birtokhoz jutása a kikötőkben gazdaságilag különböző következményekkel járt. Többségükben növekedett a forgalom, ami nem csupán a vonzóbb berendezéseknek, hanem az óriási kínai tengeri társaságok hajói gyakoribb megjelenésének, a kereskedelem élénküléseinek tulajdonítható. A leglátványosabb sikereket azok a kikötők könyvelhették el, amelyek forgalmi csomóponttá válhattak, vagy az óceánpartról egyenesen Kína belsejébe vezető, új közlekedési korridorok forgalomtápláló indulópontjainak szerepét tölthették be.

Európában már tucatnyi kikötőben van jelen a kínai tőke. Közülük eddig a legsikeresebbnek Pireusz bizonyult, ahol a 2005. évi 0,9 millióról 2019-re 5,1 millió TEU-ra szökött fel a konténerforgalom - miután a COSCO (a legnagyobb kínai tengerhajózási társaság) ott rendezte be a kelet-mediterráneumbeli disztribúciós központját (3. táblázat) [32].

\subsection{Nemzetközi reagálások az MSR-re}

Részben a - közvetett vagy közvetlen módon - közrejátszó érdekektől és más tényezőktől befolyásoltan a kezdeményezés visszhangja a pártoló véleménytôl az egészében megértő (ám egyes részkérdésekben a kockázatokról sem megfeledkező kritikus) hozzáállásokon keresztül a veszélyesnek láttató elutasításig terjedő széles skálán rendkívül sokféle.

$\mathrm{Az}$ anyagi csődtől megmentett (illetve fejlesztésekkel kedvezményezett) aktuális kormányok Délkelet- és Dél-Ázsiában, Afrikában és 
Dél-Európában áldásnak élték meg a kezdeményezést. (Utódjaik már gyakran más véleményen vannak.)

Az „Új Selyemút” terv létrehozásával szemben egészében megértő álláspontot képvisel Eszterhai Viktor [34], aki lényegében léptékazonosságot lát a globális nagyhatalmi pozícióra törekvő ország és az általa meghirdetett, sok országot felölelö program között. Ugyanakkor a kockázatok/kihívások közül kiemeli a terv pénzügyi megalapozottságával kapcsolatos bizonytalanságokat, a terrorizmust, és a megfelelő végrehajtó struktúra hiányát.

A Selyemút „románca” kevés szereplőt nyer meg Nyugat-Európában, mert nem látják eléggé bizonyítottnak, hogy Európa is érdemben részesül a Kína által hirdetett, az MSR révén keltett fellendülésből. Ezért az ígéretekkel szembeni „passzív szkepticizmus” a jellemző a fejlett országokban.

Az EU magatartása meglehetősen ambivalens. Egyfelől Pekinget „rendszerrebellisnek”, azaz az európai normákat figyelmen kívül hagyónak tekinti, és több európai ország óvatosan elhatárolódik a B\&R-től. Ezzel szemben az EU egyes hivatalos dokumentumai világosan kifejezésre juttatják, hogy létfontosságú az infrastruktúra kapcsolatok fejlesztése a Kínával való együttmüködés keretében [35].

Az MSR kezdeményezés leginkább az IndoPacific térség gazdasági hatalmainak körében tünik nemkívánatosnak. Békeidőben Kína érdemi külső reakció nélkül tesztelheti gazdasági/katonai terjeszkedésének fizikai és politikai határait. Ebben látható módon nem értékeli különösebb akadálynak az Egyesült Államok, India, Ausztrália és Japán (és az általuk alkotott regionális szövetség) nem titkolt rosszallását. E négy „tengeri demokrácia” ugyan már 2004-ben létrehozta a „Négyoldalú Biztonsági Párbeszédet”; azonban csak évtized múltával jutottak oda, hogy felismerték a veszélyt és egyben a felelősségüket Kína rendkívül gyors terjeszkedésében a számukra is fontos térségben. Ezért immár „Quad 2.0” megnevezéssel szorosabbra füzték szervezeti kapcsolatukat [36].
Közös céljuk, hogy egyeztetett módon (erősödő konvergenciával) tevékenykedjenek a szabad és nyitott Indo-Pacific régió érdekében. Azonban az általuk képviselt politikai és gazdasági potenciál még a 2010-es évek vége felé is alacsony szinten kihasznált és operacionalizált maradt.

Kína és a „Négyek” tagjai közötti közös problémákon túlmenően különlegesek is bőven adódnak. Így pl. abból, hogy Délkelet-Ázsia déli szigetvilágán részlegesen átfedi egymást Kina és Ausztrália gazdasági érdekszférája. Pápua Új-Guinea ásványi kincseire és mezőgazdasági terményeire mindkét fél beruházói igényt tartanak.

Indiát pedig (többek között) az nyugtalanítja, hogy déli tőszomszédságában Sri Lankán a külkereskedelmével kapcsolatos disztribúciós feladatot ellátó Colombo és Hambantota kikötőben minden a kínai érdekek szerint történik. Ezért rendkívül gyors konténerterminál fejlesztéssel elérte, hogy 2019-ben Mumbaiban a transshipment aránya (a forgalomátterelés következtében) már 48\%-nál tartott.

Végső soron az MSR projektek nem kizárólag gazdasági/kereskedelmi indíttatásúak, mint ahogyan nem is csupán katonai érdekeket szolgálnak. Valószínü, hogy a rendeltetésük még kínai részről sem kiforrott, kialakulóban van. Ezért egyoldalúnak látszik az olyan megítélés, hogy az MSR a kínai vezetés által koncipiált átfogó nemzeti stratégia részeként - kizárólag a hatalomról és a befolyásolásról szól [37].

\section{A VASÚTI KÖZLEKEDÉS HELYE A B\&R KEZDEMÉNYEZÉSBEN}

Összességében a szállítási volumen alapján a vasút súlya az MSR-hez képest erősen másodlagos szerepet tölt be. A B\&R keretében működő és nagy teljesítményűvé fejlesztendő vasutak földrajzi funkcióik alapján három csoportot alkotnak:

- a Kínát (Közép-Ázsián és/vagy Szibérián keresztül) Európával összekötő transzeurázsiai földhíd (Landbridge),

- az Indiai-óceán külföldi kikötői és Kína belső tartományai között épülő (a tengeri 
útvonalat lerövidítő, a Malaka-szoros elkerülését lehetővé tevő) új vasutak,

- a Kínával földrajzilag összeköttetésben nem levő, de a B\&R-hez csatlakozó ország számára kínai segítséggel épülő délkeletázsiai és afrikai vasutak.

Az első két csoport és a harmadik egy része a $B \& R 6$ gazdasági folyosójának gerincét alkotja - a nemzetközi fóutakkal együtt [38].

E folyosókat a hivatalos B\&R koncepció helyi és regionális jelentőségü gazdasági és kulturális központokat felfüző különböző mértékü fejlesztésre váró nemzetközi övezeteknek tekinti.

\section{A KÍNÁT EURÓPÁVAL ÖSSZEKÖTŐ TRANSZEURÁZSIAI SELYEMÚT}

A világtengerektöl elzárt közép-ázsiai országok hátrányaik mérséklése érdekében olyan nagyteljesítményű pályát igényeltek, amely a világgazdaság fejlett erőközpontjába (a legnagyobb beszerzési és értékesítési piacterületekre), illetve a globális gazdaságban eminens szerepet játszó kínai tengeri kikötőkbe vezet. Szándékuk találkozott az Európai Közösség gazdasági expanziós törekvéseivel, és 1993-ban Bakuban aláírták az érdekelt országok a TRACECA multilaterális egyezményt. Az EU-nak az volt a célja, hogy Oroszország elkerülésével teremtsen rövidebb összeköttetést a FÁK-országokkal és a kínai kikötőkkel. Ugyan a közép-ázsiai országok között kisebb vonalkorrekciókkal és kétoldalú szerződésekkel helyenként javult a hálózat teljesítőképessége, a TRACECA nem váltotta be a hozzá füzött reményt, az EU közreműködése is messze elmaradt az elvárttól.

2011-ben azonban létrejött a második kapcsolat Kína és Kazahsztán között (Khorgas), amely növelte az átrakó kapacitást a különböző nyomtávú hálózatok között.

Az attól délnyugati irányban Üzbegisztánon és Türkmenisztánon át közlekedő tehervonatok az iráni határon ismét nyomvonalváltásra kényszerültek. Iránból Törökországon keresztül Európába normálnyomtávú vasúti öszszeköttetés állt rendelkezésre. Azonban ezen belül a Van-tavon és a Boszporuszon kompok igénybevételére kényszerültek a szerelvények. Semmivel sem volt vonzóbb a Türkmenisztán-Kaszpi-tenger-Kaukázus-Fekete-tenger változat a kaukázusi országok közötti harcok miatt. El is jelentéktelenedett Baku szerepe a nemzetközi tranzitban [39].

E helyzetben Kazahsztán megtalálta a modus vivendit azzal, hogy a saját területén keresztül északnyugat irányban vezetö felújított fövonalán közlekedtetett nemzetközi tehervonatokkal az Uráltól délre eléri az oroszországi hálózatot.

Egyelöre Ukrajna helyett Belaruszon keresztül érik el a Kínából induló konténervonatok a lengyelországi (normálnyomtávú) hálózatot és azon keresztül Nyugat-Európát.

A 2010-es években ismét vonzóbbá váltak a déli vonalláncok több kulcsfontosságú szakasz megépülésének köszönhetöen:

- kínai támogatással 2013-ra elkészült a Bakut Kelet-Törökországgal (Kars) Tbiliszin keresztül összekötő (BTK) vasút,

- a Boszporusz alatt pedig 2015-ben a Marmaray-alagút, amely eleinte azonban csak Isztambul helyi és elővárosi kötöttpályás forgalmát szolgálta [40].

A hagyományos és legrövidebb TürkmenbaşyBaku viszonylatú vasúti komp működésének zavarait kihasználva Kazahsztán Azerbajdzsánnal összefogva korszerű hajókkal jól müködő kompvonalat szervezett Aktau és Baku között. Ezzel lehetőség nyílott arra, hogy Kína és a Kaukázus térség/Törökország között konténervonatok közlekedjenek. E vonal értékét igazán az növelte, hogy Törökország a Marmaray-alagutat a transzeurázsiai útvonal szerves részévé léptette elő. Így 2019. októbertől a kínai kikötők és az európai desztinációk (pl. Prága, Łódź, Veneto) között közlekedő tehervonatoknak már nem kell kompokat igénybe venni Isztambulban [41].

Az immár NATO-tag Grúzia periférikus helyzetét új, nagy kapacitású kikötő (Anaklia) építésével igyekszik javítani, arra számítva, hogy közvetítője lehet a Fekete-tengeren keresztül zajló, Dél-Ukrajnát, Moldáviát és Romániát kiszolgáló kínai vonatkozású kombinált szállí- 
tásnak [42]. Egyelőre Batumi/Poti-Konstanca viszonylatban a legintenzívebb a $B \& R$ transzeurázsiai folyosóba illeszkedő komphajózás [43].

Ugyan a Marmaray-alagú igénybevétele óta a Törökországon keresztül áramló tranzitforgalom megtöbbszöröződött, a Kína és Európa közötti vasúti konténerszállítás 68\%-a még mindig a jól bevált Kazahsztán-OroszországBelarusz-Lengyelország vasúti összeköttetést vette igénybe 2018-ban [44]. Annak ellenére, hogy az Európai Bizottság és a Világbank által létrehozott Indicative Investment Plan Oroszországgal szemben előnyben részesíti a két kaukázusi országot, és hogy a „Baku International Sea Trade Port” társaság egy hatalmas, kialakulóban levő szabadkereskedelmi zóna irányítójaként létrehozta Alatban a termelési központját, amely közlekedési kapcsolatban van Törökországgal, az EU-országokkal, Iránnal, Indiával és Oroszországgal.

Kina a $B \& R$ szerkesztésekor és továbbfejlesztésekor nem foglalt egyértelmüen állást a tekintetben, hogy melyik transzeurázsiai vonalváltozatot preferálja [45]. Ezt a magatartást érthetővé teszi a rendkívül sokirányú és időben változó külkereskedelme mind a tranzittérséggel (Oroszország, Kazahsztán, KözépÁzsia, Irán, Törökország, kaukázusi országok, Belarusz), mind az európai desztinációkkal. Oroszország az ezredfordulón még arra számított, hogy a Kína által keltett forgalom nagyobb részét képes lesz a Transzszib magához vonzani. (Meg is történt teljes hosszban a villamosítása és a kétvágányúsítása.) Ezzel szemben a transzszibériai vasúti forgalomnak csupán 10-15\%-a áramlik e klasszikus északi vonalon, kevesebb a tranzitból származó bevétele. (Az érem másik oldala, hogy nem nehezíti zsúfoltság a szibériai nyersanyagok, energiahordozók tömeges exportját, továbbá a lakosság ellátásában egyre nagyobb szerepet játszó áruimportot.)

\section{A KÍNA ÉS EURÓPA KÖZÖTTI (KÉTIRÁNYÚ) VASÚTI FORGALOM}

Természetes, hogy a szárazföldi szállításra nagyobb gondot kell fordítani, de figyelembe kell venni a reális lehetőségeket: egy széles nyomtávú, rendkívül hosszú szibériai vonat max. 80-100 TEU konténert képes mozgatni, a nagy hajók viszont 12-20 ezer TEU egységet. A hajoút részarányát radikálisan csak a Szuezi-csatorna használhatatlanná válása csökkentheti átmenetileg. Tehát továbbra is csupán kiegészítö szerepet játszhat a vasút interkontinentális viszonylatban; a fajlagosan nagy értékü és érzékeny áruk képezik a stabil tételt a szállítmányok körében.

Bár az eredeti, a szárazföldi közlekedésre alapozott „Új Selyemút” koncepcióban a vasút megkülönböztetett szerepet kapott és a konténeres forgalom századunkban megélénkült, értékalapon így is csak $2,1 \%$ a vasút részaránya, de tonnasúlyát tekintve még az 1,0\%-ot sem éri el.

A transzeurázsiai nemzetközi vasúti teherforgalom letéteményesei elsősorban a konténerszállításra szakosodott vegyesvállalatok, melyek teljesítménye elérte az évi 370 ezer TEU-t.

A Kína és Európa közötti viszonylatokban az irányvonatok müködése igazából századunkban bontakozott ki. 2008-ban a Foxconn indította az első vonatot Shenzhenből Európába. Ezt követően számos kínai kikötőből és a partoktól távoli nagy ipari központokból a német kikötők, sőt Olaszország, Spanyolország és Anglia (!) felé is igény mutatkozott a 12-20 nap menetidő igényű kombinált szállításra. Ebből 4-5 napot még mindig az országhatárokon való várakozás (vámvizsgálat, biztonsági ellenőrzés, mozdonycsere, a vasúti kocsik müszaki átvizsgálása, adminisztráció) veszi igénybe [46].

2018-ban 1470 irányvonat közlekedett 48 kínai és 42 európai desztináció között (azaz naponta átlagosan négy szerelvény) és szervezés alatt volt Vietnám bevonása is [47].

A forgalmi irányok erős egyensúlytalansága (nyugati 60-70\%, keleti 30-40\% közötti arány) miatt sok üres konténert kell visszaszállítani Európából, ami növeli a teljes szállítási költséget. A költségnövelö egyensúlytalanságot újabban mérsékli, hogy Kína egyre több európai árura tart igényt. 
Legújabban az európai országok fele igénybe veszi az irányvonatok szolgáltatásait a magasabb értékü és a szállításra fizikailag érzékeny áruk (számítógép, nyomtató, monitor, tévékészülék stb.) Kínából történő behozatalához. Ezért e gyorsan bővülö vasúti szolgáltatásfajtának jótékony hatása van az e termékeket előállító, és egyre inkább Nyugat-Kínában (zömmel Csunking térségében) összpontosuló exportorientált iparágakra (pl. laptop gyártás). Ellenben az Európából Kínába irányuló exportra nincs különösebb hatása a vasúti kapcsolatoknak. A meglehetősen szerény tömegü szállítmányok egyharmadát autóalkatrészek képezik, miután Kína (jobbára európai és japán autóipari cégektől vett licencekre alapozottan) már a világ legnagyobb gépkocsiiparát müködteti [48].

\section{KÍNA KÜLFÖLDI NAGYSEBESSÉ- GÜ ÉS HAGYOMÁNYOS VASÚT- ÉPÍTÉSEI A B\&R KERETÉBEN}

Kína egyedülálló méretű és minőségű vasúti gerinchálózatának létrehozása közben kiforrott müszaki/építési tapasztalatok és technológiai megoldások birtokában közel 10 ezer km hosszú vasúttal gazdagítja Ázsia és Afrika fél tucat országát. Technológiai felkészültségére utal, hogy a Shinkansen-nél nagyobb maximális sebességet érnek el szupervonatjai.

Az új, nagyobbrészt már épülőfélben levő hagyományos és nagysebességü vasutak oroszlánrésze a gazdasági nagyhatalomhoz ezernyi szállal kötődő érdekszférájában, Délkelet-Ázsiában összpontosul. Az ottani új pályahálózat része az ENSZ Gazdasági Bizottságának támogatását élvező Trans-Asian Railwaynek. A Kínához viszonyított földrajzi helyzetük alapján e vasutak három csoportot alkotnak.

a) A Kinával földrajzilag kapcsolatban nem levő Indonéziában épül az ország első nagysebességű vasútja Dzsakarta (föváros) és a nemzetközi tanácskozások emblematikus városa, Bandung között [49]. A világ legrövidebb $(140 \mathrm{~km})$ „szóló” nagysebességü vasútjának tenderét Japánnal szemben Kína azzal nyerte el, hogy nem kért állami kezességvállalást. b) A Kínával szárazföldön összeköttetést létesítő vasutak/pályaláncok

ba) Malaka-szoros kiiktatását, elkerülését célzó vasutak

- Mianmarban, a Bengáli-öböl partján felfejlesztett Kyaukpyu kikötőből induló és a periférikus fekvésű kínai Kunming közötti energiakorridort kiegészítő vasút építéséről kötött szerződést Kína előbb-utóbb valóra váltja.

- A pakisztáni Gwadar kikötőt a nyugatkínai Kashgarral összekötő vasút tervei is megvalósításra várnak [50].

bb) A Szingapúr-Malajzia-Thaiföld-LaoszKina (müszakilag egyelöre összehangolatlan) heterogén $3000 \mathrm{~km}$-nél is hosszabb vasúti összeköttetés Kína szempontjából akár csupán presztízs beruházásnak is tünhet, azonban valójában a kényszerhelyzet produktuma. A már említett Kunming számára a vietnámi Haiphong kikötő ugyan jóval közelebb van mint Bangkok, azonban a Vietnámmal elhidegült politikai viszony miatt ez az opció kimaradt a tervezésből. Ezért Kínából Laoszon keresztül Thaiföld felé indult el a vasútépítkezés 2016 decemberében (Laosz a kevés vasút nélküli országok egyike volt). A fövárosig (Vientiane) tartó szakasz munkálatai 2021-ben fejeződnek be. Költségének 70\%-át Kína állja, míg a többi 30\%-ot Laosz ásványi nyersanyagexportból fedezi. Ezzel Kína Mianmar mellett már Thaiföld kikötőit is igénybe veheti Jünnan és Kujcsou tartományok számára. Ezekhez képest a malajziai kikötők és Szingapúr a távolságuk miatt gateway szerepet érdemi mértékben nem játszanak a kínai külkereskedelemben, viszont a kínai mélyépítő vállalatok számára nagy nyereséget ígérő a több országon végigvonuló vasúti összeköttetés tervezése és kivitelezése. Csupán a thaiföldi nagysebességü hálózat hossza eléri a japán $55 \%$-át, de a malajziai új vasutak hossza is meghaladja az $1000 \mathrm{~km}-\mathrm{t}$ [51].

A Kína által Afrikában tucatnyi országban épített vasutak közül jelentőségében az etióp fővárost Dzsibuti kikötővel összekötő igen gyenge vonal teljes átépítése, Nigériában Abuja és Kaduna között az ország első normálnyom- 
távú pályájának 2019. januárban történt átadása, valamint a kenyai fővárost, Nairobit az ország legnagyobb kikötőjével összekötő 470 km hosszú vasút vezet [52].

\section{1. ÚJ HELYZET? (NYITOTT KÉRDÉSEK)}

Elterjedt az a nézet 2020 tavaszán, hogy a pandémia leküzdése után átalakul a világgazdaság:

- a globalizációs folyamatok sokat veszítenek hajtóenergiájukból; nevezetesen a távolsági gazdasági/turisztikai kapcsolatok elerőtlenednek, lazul a meghatározó gazdasági erőközpontoktól való függés, miközben

- a helyi, illetve nemzetgazdaságok felértékelődnek ellátási, értéktermelési és foglalkoztatási szempontból is.

Kínára vonatkoztatva ez azt jelenti, hogy igencsak csökken a szerepe a világ iparcikk ellátásában. Drasztikus kivitel visszaesés után a termelés szinten tartása csak a belső fogyasztás lényeges növelésével lehetséges.

Kérdés, hogy a kényszeredett befelé fordulás meddig tart, milyen hatással lehet a $B \& R$ projekt 2049-ig történő befejezésére. Úgy gondoljuk, hogy a tengeri export visszaesése csak addig tart, ameddig a világgazdasági krízis. Feltételezhetö, hogy Kina külkereskedelme ugyan hosszabb távon is elmarad a 2019. évitöl, de világelső pozícióját megőrzi.

Nehezen elképzelhető, hogy a B\&R-be befektetett óriási összegek megtérüléséről, a több világrészen létesített (kész és épülőfélben levő) hatalmas közlekedési infrastruktúráról Kína lemondjon. Sőt, a gazdasági nehézségeket kihasználva a kinai kikötöüzemeltetö és tengerhajózási társaságok tovább terjeszkedhetnek még Európa kikötőállományában is.

A pandémiát a legkisebb veszteség árán maga mögött tudó gazdasági (és legújabban technológiai) világhatalom tervszerüen dolgozik az amerikait felváltó „sinoglobalizáció” megvalósulásán, amelynek conditio sine qua nonja a saját kézben levő globális közlekedési/távközlési hálózat.

\section{2. ÖSSZEFOGLALÁS}

Gazdasági szuperhatalomként a globális kereskedelemben Kína megelőzte az Egyesült Államokat. A legnagyobb partnerével, Európával összekötő tengeri útvonal hajózhatóságát időnként különféle történések nehezítik, ahogyan a transzeurázsiai korridorokat is. Exportvezérelt gazdasága Kínát arra késztette, hogy minimalizálja nemzetközi szállítási útvonalai használatának kockázatát. Ezért 2013ban meghirdette a három kontinensre kiterjedő, 2049-ig tartó „Övezet és Út” szemiglobális infrastruktúra-fejlesztési gigaprojektet trillió dollár nagyságrendü finanszírozási háttérrel.

A tengeri útvonal biztonságát Kína a kikötőkben való masszív gazdasági (szükség esetén haditengerészeti) jelenléttel, az adott ország lojalitását pedig jelentős, a fejlődést elősegítő beruházásokkal segíti elö. Mindemellett a világ legnagyobb működő tőke „exportőreként” gazdasági hatása még Nyugat-Európa kikötőrégióiban is érvényesül.

A transzeurázsiai vasutak több változatban kínálnak konténer irányvonatokkal összeköttetést félszáz kínai és ugyanennyi európai desztináció között. A széles és normálnyomtáv váltakozásából adódó gondok ellenére a gazdasági struktúraváltás nyomán növekszik a nagy értékű és időérzékeny műszaki cikkek vasúti forgalma. Új fejezet kezdődhet, ha Kína létrehozza a tervezett nagy teljesítőképességü normálnyomtávú vasutat Közép-Európáig.

A pandémia után a globalizáció hajtó ereje gyengülhet, és Kína gazdasága (a belföldi fogyasztás növekedése mellett) már kevésbé lesz exportorientált. Azonban Kína nem mond le a $B \& R$ gigaprojekt befejezéséröl, mert az amerikait felváltó sinoglobalizáció nélkülözhetetlen eszköze a saját kézben levő globális közlekedési hálózat.

\section{FELHASZNÁLT IRODALOM}

[1] Erdősi F. (2017): A Közel-Kelet közlekedése. Publikon Kiadó, Pécs.

[2] Kuo, L., Kommenda, N. (2008): What is China's Belt and Road Initiative? The Guar- 
dian, július 30. https://www.theguardian. com/cities/ng-interactive/2018/jul/30/ what-china-belt-road-initiative-silk-roadexplainer

[3] Nobis, A. (2017): The New Silk Road, Old Concepts of Globalization, and New Questions. Open Cultural Studies, 1. p. 203-213.

[4] Clinton, H. (2011): Remarks on India and the United States: A Vision for the 21st Century. https://2009-2017. state.gov/secretary/20092013clinton/ $\mathrm{rm} / 2011 / 07 / 168840 . \mathrm{htm}$

[5] Fardella, E., Prodi, G. (2017): The Belt and Road Initiative Impact on Europe: An Italian Perspective. China \& World Economy, Vol. 25. No. 5. p. 125-138. DOI: http://doi.org/d7gf

[6] Miller, T. (2017): China's Asian Dream: Empire Building along the New Silk Road. Zed Books, London.

[7] Frankopan, B. (2019): Die neuen Seidenstraßen: Gegenwart und Zukunft unserer Welt. . Rowohlt, Berlin.

[8] Noesselt, N. (2018): Die „Neue Seidenstraße" zwischen Mythos und Geopolitik. Budrich Journals, 2. p. 191-202. DOI: http://doi.org/d7gg

[9] Woetzel, J., Seong, J., Leung, N., Ngai, J., Manyika, J., Madgavkar, A., Lund, S., Mironenko, A. (2018): The relationship between China and the world. McKinsey \& Company.

[10] Vision and Actions on Jointly Building Silk Road Economic Belt and 21st-Century Maritime Silk Road. Issued by the National Development and Reform Commission, Ministry of Foreign Affairs, and Ministry of Commerce of the People's Republic of China, with State Council authorization, March 2015, II. Principles. http://en.ndrc.gov. cn/newsrelease/201503/t20150330_669367. html

[11] Wang, Y. (2018): The Belt and Road: What Will China Offer the World in Its Rise. New World Press, Peking

[12] Steck, G. (2018): China's Belt and Road Initiative is Neither a Strategy, Nor a Vision. It is a Process. European Institute for Asian Studies, Brussels.

[13] China and the world: Inside the dynamics of a changing relationship. McKinsey Global Institute, July 2019.

[14] Fardella, E., Prodi, G. (2017): i. m.

[15] Lee, F. (2019):China:Hinter der Seidenstraße steckt Geopolitik. Südkurier, 02. Mai. https:/www.suedkurier.de/ueberregional/ politik/Hinter-der-Seidenstrasse-stecktGeopolitik;art410924,10135531

[16] Eszterhai V. (2016): Az „Új Selyemút” terv. Eszmélet, 28. évf. 109. sz. p. 116-131.

[17] Stephens, T. (2019): Swiss president strengthens economic ties with China. swissinfo.ch. 28 May 2019. https://www. swissinfo.ch/eng/state-visit_swisspresident-strengthens-economic-ties-withchina-/44926898.

[18] YU, H. (2017): Motivation behind China's 'One Belt, One Road' Initiatives and Establishment of the Asian Infrastructure Investment Bank. Journal of Contemporary China, Vol. 26. No. 105. p. 353-368. DOI: http://doi.org/gfwnkx

[19] Klemensits, P. (2017): China and the 21st Century New Maritime Silk Road. Belt \& Road Center, 23 October http://beltandroadcenter.org/2017/10/23/ china-and-the-21st-century-newmaritime-silk-road/

[20] van der Putten, F-P., Meijnders, M. (2016): China, Europe and the Maritime Silk Road. Clingendael Institute, Hague. h t t p s : / / www.clingendael.org/sites/default/files/ pdfs/China_Maritime_Silk_Road.pdf

[21] ISL Shipping Statistics Yearbook - Bremen 1975-2019. évi kötetei.

[22] Green, M. J. (2018): China's Maritime Silk Road: Strategic and Economic Implications for the Indo-Pacific Region. CSIS, 2 April. https://www.csis.org/analysis/ chinas-maritime-silk-road

[23] Seidler, F. (2013): Maritime Machtverschiebungen im IndoPazifischen Raum: Geopolitische und strategische Trends. Kieler Analysen zur Sicherheitspolitik Nr. 33 Januar. Institut für Sicherheits Politik an der ChristianAlbrechts-Universität zu Kiel.

[24] Szechenyi, N. (szerk.) (2018): China's Maritime Silk Road. Strategic and Economic Implications for the Indo-Pacific Region. Center for Strategic \& International 
Studies.

[25] Erdősi F. (2013): A közeledő Távol-Kelet. Publikon Kiadó, Pécs.

[26] Axe, D. (2019): Diego Garcia: Why This Base Is About To Get Much More Important to the U.S. Military. The National Interest, February 26. https://nationalinterest. org/blog/buzz/diego-garcia-why-baseabout-get-much-more-important-usmilitary-45682

[27] Petróczki M. (2019): A Malaka-szoros és a Thai-csatorna geopolitikai harca. Biztonságpolitika, április. 3. h t t p s:// biztonsagpolitika.hu/egyeb/a-malakaszoros-es-a-thai-csatorna-geopolitikaiharca

[28] Schröder, B. (2018): Wie China das Malakka-Dilemma umschiffen will. https:// www.heise.de/tp/features/Wie-Chinadas-Malakka-Dilemma-umschiffenwill-4038728.html?seite $=$ all

[29] Data Tell: Ports light up the 21st Century Maritime silk Road. https://www. hellenicshippingnews.com/data-tellsports-light-up-the-21st-century-maritimesilk-road/

[30] Unraveling the Maritime Silk Road. Belt and Road, New January 5, 2019. https:// www.beltandroad.news $/ 2019 / 01 / 05 /$ unraveling-the-maritime-silk-road/

[31] China Unveils Action Plan on Maritime Silk Road. https://www.marinelink.com/ news/maritime-unveils-action 388448

[32] China's COSCO Plan: Make Piraeus Europe's Biggest Port. The National Herald, November 18, 2019. h t t p s : / / w w w . thenationalherald.com $/ 268879 /$ chinascosco-plan-make-piraeus-europes-biggestport/

[33] Pandya, S., Tagliapietra, S. (2018): China's strategic investments in Europe: The case of maritime ports. $\quad \mathrm{h} \mathrm{t} \mathrm{t} \mathrm{p} \mathrm{s://}$ www.bruegel.org/2018/06/chinas-strategicinvestments-in-europe-the-case-ofmaritime-ports/

[34] Eszterhai V. (2016): i. m.

[35] Investment Plan for Europe (2015). European Investment Bank. https://www.eib.org/ attachments/thematic/investment_plan_ for_europe_en.pdf

[36] Gale, J. B., Shearer, A. (2018): The
Quadrilateral Security Dialogue and the Maritime Silk Road Initiative. In: Szechenyi, N. (ed.): China's Maritime Silk Road. Center for Strategic \& International Studies, p. 30-33.

[37] Mohan, G. (2018): Gefährliches Spiel um die Vorherrschaft im Indischen Ozean. Neue Zürcher Zeitung, 26. Mai. h t t p s : / / www.nzz.ch/meinung/gefaehrliches-spielum-die-vorherrschaft-im-indischen-ozeanld. 1382515

[38] Derudder, B., Liu, X., Kunaka, C., Robers, M. (2014): The connectivity of South Asian cities in infrastructure networks. Journal of Maps, Vol. 10. No. 1. p. 47-52.

[39] Erdősi F. (2013): i. m.

[40] Erdősi F. (2017): i. m.

[41] Calabrese, J. (2019): Setting the Middle Corridor on track. https://www.mei.edu/ publications/setting-middle-corridor-track

[42] Welt, C. (2019): Georgia: Background and U.S. Policy. CRS Report for Congress. https://www.hsdl.org/?view\&did=830625

[43] Grampet partners with ASCO to open Constanta-Batumi shipping route. Ship Technology, October 24. https://www. ship-technology.com/news/grampet-ascoconstanta-batumi-shipping/

[44] Kazakhstan expects more containers from China. Rail Freight.com. 23.01.2020. ht t p s://ww w.railfreight.com/ beltandroad/2020/01/23/kazakhstanexpects-more-containers-from-china/

[45] Knowler, G. (2019): Maersk ocean-rail service adds new wrinkle to Asia-Europe. Journal of Commerce, August 7. https:// www.joc.com/rail-intermodal/maerskocean-rail-service-adds-new-wrinkle-asiaeurope_20190807.html

[46] Rodemann, H., Templar, S. (2014): The enablers and inhibitors of intermodal rail freight between Asia and Europe. Journal of Rail Transport Planning \& Management, 4 (3) p. 70-86. DOI: http://doi.org/d7gh

[47] China-Europe Freight Train Service Extended Southwards to Vietnam. Xinhua Net, 18 March 2018. http://www.xinhuanet. com/english/2018-03/18/c_137047977.htm

[48] Hoefer, C. (2019): Die stählerne Seidenstraße wächst rasant. https://www. manager-magazin.de/lifestyle/artikel/ 
seidenstrasse-gueterzugverkehr-aus-chinanimmt-deutlich-zu-a-1272676.html

[49] Jakarta-Bandung railway project won't meet target, Minister. (https://www. thejakartapost.com/news/2018/02/19/ jakarta-bandung-railway-project-wontmeet-target-minister.html)

[50] Kanwal, G. (2018): Pakistan's Gwadar Port: A New Naval Base in China's String of Pearls in the Indo-Pacific. CSIS, April 2. https://www.csis.org/analysis/pakistansgwadar-port-new-naval-base-chinasstring-pearls-indo-pacific
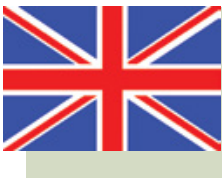

\section{The largest international transport development project in the world history}

The article introduces to Hungarian readers the semiglobal transport infrastructure development giga project (until 2049) announced by China (2013), the economic superpower, and its expected effects. For its export-oriented economy and other reasons, it is vital for China to minimize the risk of using the sea route to Europe and to the trans-European railways. Therefore, the author has mostly a permissive attitude toward the Chinese ownership of many port in the Indian Ocean and Europe that are occasionally servicing warships as well.

Although the acquisition of some ports is not in conflict with international law, but its nonethical approach also generally brings economic benefits to the countries concerned. Due to their lack of interoperability, rail corridors are in need of the container transport of high-value technical goods. The author presumes (as opposed to many "predictions") that the coronavirus epidemic will not bring about a substantial change is freight transport between China and Europe in the medium term (due to interdependence). As the main patron of underdeveloped countries, China endeavors to create a robust infrastructure in Asia and Africa.

It can be assumed that China will not give up on Sino globalization, which will replace American-type globalization, even in the postpandemic changing world economy. It is therefore completing its global transport network.
[51] Back on track: ECRL to resume at RM 44 billion. New Straits Times, 12 April 2019. https://www.nst.com.my/news/ nation/2019/04/478726/back-track-ecrlresume-rm-44-billion

[52] Xinhua Headlines: One year on, Chinesebuilt railway revitalizes regional trade in Kenya. Xinhua Net. 1 June 2018.

http://www.xinhuanet.com/english/201806/01/c_137223294.htm

\section{Das größte internationale Verkehrsentwicklungspro- jekt der Weltgeschichte}

Der Artikel stellt den ungarischen Lesern das von China (2013) angekündigte semiglobale Giga-Projekt zur Entwicklung der Verkehrsinfrastruktur (bis 2049), die wirtschaftliche Supermacht und ihre erwarteten Auswirkungen vor. Wegen der exportorientierten Wirtschaft und aus anderen Gründen ist es für China von entscheidender Bedeutung, das Risiko der Nutzung des Seewegs zu Europa und zu den transeuropäischen Eisenbahnen zu minimieren. Daher hat der Autor größtenteils eine freizügige Haltung gegenüber dem chinesischen Besitz vieler Häfen im Indischen Ozean und in Europa, die gelegentlich auch Kriegsschiffe bedienen.

Der Erwerb einiger Häfen steht zwar nicht im Widerspruch zum internationalen Recht, aber sein unethischer Ansatz bringt den betroffenen Ländern im Allgemeinen auch wirtschaftliche Vorteile. Aufgrund ihrer mangelnden Interoperabilität benötigen Eisenbahnkorridore den Containertransport hochwertiger technischer Güter. Der Autor geht (im Gegensatz zu vielen „Vorhersagen") davon aus, dass die Coronavirus-Epidemie mittelfristig (aufgrund der gegenseitigen Abhängigkeit) keine wesentliche Änderung des Güterverkehrs zwischen China und Europa bewirken wird. Als Hauptpatron der unterentwickelten Länder strebt China an, eine robuste Infrastruktur in Asien und Afrika aufzubauen.

Es ist davon auszugehen, dass China die chinesische Globalisierung nicht aufgeben wird, die die Globalisierung nach amerikanischem Vorbild ersetzen wird, selbst in der sich durch die nach der Pandemie verändernden Weltwirtschaft. Damit vervollständigt es sein globales Verkehrsnetz. 